\title{
AIR EMPHYSEMA AFTER DRYING THE CAVITY WITH AN AIR SYRINGE
}

\author{
Ewa Marek' ${ }^{1}$, Katarzyna Kot ${ }^{1}$, Adam Kozłowski' ${ }^{2}$, Mariusz Lipski ${ }^{1}$ \\ 'Department of Preclinical Conservative Dentistry and Preclinical Endodontics, Pomeranian Medical University, Szczecin, Poland \\ 2Private Practice Ka-dent, Szczecin, Poland
}

\begin{abstract}
INTRODUCTION: Subcutaneous emphysema is defined as the abnormal presence of air or gas in the body tissues or tissue spaces. In dentistry, however, subcutaneous emphysema is most often a consequence of compressed air being forced into the subcutaneous tissues through the intra-oral barrier. Most often the air comes from the slow hand-piece, the turbine and the dental air syringe, although recent reports have surfaced of emphysema being caused by air coming from an air abrasion tool, $\mathrm{CO}_{2}$ laser or a cryotherapy device.

CASE DeSCRIPTION: A case of air emphysema following by drying the cavity with dental syringe. Discussion of prophylactic and treatment of air emphysema.

Conclusions: Subcutaneous emphysema is one of the less common complications that may occur during the treatment of carious lesions. It is usually limited to moderate swelling of soft tissues, which due to slow regression becomes an unpleasant complication for the patient. The air that has entered to the subcutaneous tissue carries the risk of causing an infection like cellulitis or necrosis of fascial and therefore requires the use of antibiotic therapy. Although emphysema is a medical complication, often harmless, it should be remembered that there is always a risk of serious consequences requiring specialized treatment. Prompt and appropriate diagnosis enables effective treatment of emphysema.
\end{abstract}

KEY wORDs: emphysema, complications, dental treatment.

J Stoma 2018; 71, 5: 444-448

DOI: https://doi.org/10.5114/jos.2018.84767

\section{INTRODUCTION}

Subcutaneous emphysema is defined as an unnatural collection of air or other gas in tissues or tissue spaces [1]. It may occur spontaneously, iatrogenically or as a result of a sustained injury [2]. Intrinsic (spontaneous) subcutaneous emphysema can occur, for example, when blowing a nose, sneezing or playing a brass instrument. Traumatic emphysema arises as a result of injuries sustained in the craniofacial region. In turn, iatrogenic emphysema is a result of medical malpractice committed by a physician during the diagnosis or treatment of the pa- tient. Among treatments in the field of anaesthesiology, the most common cause of subcutaneous emphysema is poorly performed intubation or excessive ventilation of the patient $[3,4]$.

In dentistry, however, subcutaneous emphysema is most often a consequence of compressed air being forced into the subcutaneous tissues through the intra-oral barrier [5-7]. Most often the air comes from the slow handpiece, the turbine and the dental air syringe, although recent reports have surfaced of emphysema being caused by air coming from an air abrasion tool, $\mathrm{CO}_{2}$ laser or a cryotherapy device [8-12]. Procedures which entail a high

\section{JOURNAL OF} STOMATOLOGY CZASOPISMO STOMATOLOGICZNE

AdDRESS FOR CORRESPONDENCE: Ewa Marek, Department of Preclinical Conservative Dentistry and Preclinical Endodontics, Pomeranian Medical University, al. Powstańców Wlkp. 72, 70-111 Szczecin, Poland, phone: +48 9146616 30, phone/fax: +48 9146618 02, e-mail: fantom@pum.edu.pl 
risk of developing subcutaneous emphysema include extractions (especially those of third molars in the mandible), endodontic microsurgery (e.g. resections of root apex), root canal treatment, periodontal treatment (e.g. scaling), restorative dental treatment (Table 1), implantation, tooth preparation for crowns and bridges [1, 6, 7, 13-15].

\section{CASE DESCRIPTION}

A 52-year-old female patient arrived at the dentist's office for her biannual dental check-up. Over the course of the clinical examination, the patient was diagnosed with secondary caries over the filling located in the cervical area on the buccal side of tooth 44 . Before removal of the filling, a retraction thread was introduced into the gingival sulcus in order to pull the gums away from the tooth tissues and thus to avoid periodontal damage while preparing the cavity. After inserting the thread, the physician dried the tissue with a dental air syringe in order to improve the visibility in the treatment area. Immediately after drying the tooth, the facial soft tissues presented oedema on the right side along the sub-

TABLE 1. Case reports of subcutaneous ephysema occured during restorative treatment in conservative dentistry

\begin{tabular}{|c|c|c|c|c|c|c|c|}
\hline Reference & Gender & Age & Tooth & Procedure & Suspected cause & Type of emphysema & Antibiotics \\
\hline Aquillina P, McKellar G & $F$ & 31 & 26 & $\begin{array}{l}\text { Cavity preparation, } \\
\text { high speed handpiece }\end{array}$ & $\begin{array}{l}\text { Laceration in the depths } \\
\text { of the upper left buccal } \\
\text { vestibule adjacent to tooth } \\
26 \text { measuring approximately } \\
5 \mathrm{~mm} \text { in length }\end{array}$ & $\begin{array}{l}\text { Subcutaneus } \\
\text { emphysema }\end{array}$ & $\begin{array}{l}\text { Clindamicin } \\
300 \mathrm{mg} \\
(4 \times 1 \text { i.v. })\end{array}$ \\
\hline Bohnenkamp DM & M & 23 & 35 & $\begin{array}{l}\text { Occlusal reduction } \\
\text { of the facial cusp with } \\
\text { diamond bur and high } \\
\text { speed handpiece }\end{array}$ & $\begin{array}{l}\text { Laceration of buccal mucosa } \\
\text { opposite tooth } 35 \text { caused } \\
\text { by biting the cheek during } \\
\text { food mastication }\end{array}$ & $\begin{array}{l}\text { Subcutaneus } \\
\text { emphysema }\end{array}$ & 10 days \\
\hline $\begin{array}{l}\text { Chan DCN, Myers T, } \\
\text { Sharaway M, et al. }\end{array}$ & M & 47 & 44,45 & $\begin{array}{l}\text { V class cavities (air } \\
\text { coming from high } \\
\text { speed handpiece or } \\
\text { air-water syringe) }\end{array}$ & & $\begin{array}{l}\text { Subcutaneus } \\
\text { emphysema }\end{array}$ & No \\
\hline $\begin{array}{l}\text { Iqbal M, Ikram M, } \\
\text { Raza F, Banday N }\end{array}$ & $\mathrm{F}$ & 50 & $\begin{array}{l}\text { Lower } \\
\text { left } \\
\text { molar } \\
\text { tooth }\end{array}$ & $\begin{array}{l}\text { New restoration } \\
\text { of fractured crown in } \\
\text { tooth endodonticaly } \\
\text { treated } 12 \text { years } \\
\text { before (air coming } \\
\text { from air-water } \\
\text { syringe) }\end{array}$ & & $\begin{array}{l}\text { Subcutaneus } \\
\text { emphysema, } \\
\text { pre-vertebral space } \\
\text { emphysema }\end{array}$ & Yes \\
\hline $\begin{array}{l}\text { Salib RJ, Valentine P, } \\
\text { Akhtar S }\end{array}$ & $\mathrm{F}$ & 56 & 44,45 & V class cavities & & $\begin{array}{l}\text { Subcutaneus } \\
\text { emphysema }\end{array}$ & Yes \\
\hline $\begin{array}{l}\text { Libenberg WH, } \\
\text { Crawford BJ }\end{array}$ & $\mathrm{F}$ & 16 & 27 & $\begin{array}{l}\text { Cavity located in } \\
\text { palatal fissure } \\
\text { prepared by air- } \\
\text { abrasive device }\end{array}$ & $\begin{array}{l}\text { Laceration of gingival } \\
\text { mucosa caused by rubber } \\
\text { dam clamp }\end{array}$ & $\begin{array}{l}\text { Subcutaneus } \\
\text { and mediastinal } \\
\text { emphysema }\end{array}$ & $?$ \\
\hline $\begin{array}{l}\text { Steelman RJ, } \\
\text { Johannes PW }\end{array}$ & $\mathrm{F}$ & 5 & 75 & Cavity preparation & $\begin{array}{l}\text { Operculum flap covering } \\
\text { freshly erupting tooth } 36\end{array}$ & $\begin{array}{l}\text { Subcutaneus } \\
\text { emphysema, } \\
\text { mediastinal } \\
\text { emphysema }\end{array}$ & Clindamycin \\
\hline $\begin{array}{l}\text { Mather AJ, } \\
\text { Stoykewych AA, } \\
\text { Curran JB }\end{array}$ & $\mathrm{F}$ & 43 & 25 & $\begin{array}{l}\text { Cavity preparation, } \\
\text { turbine }\end{array}$ & $\begin{array}{c}\text { Thin band of attached } \\
\text { gingiva }\end{array}$ & $\begin{array}{l}\text { Subcutaneus } \\
\text { emphysema, } \\
\text { parapharyngeal and } \\
\text { retropharyngeal } \\
\text { emphysema, } \\
\text { mediastinal } \\
\text { emphysema }\end{array}$ & Yes \\
\hline $\begin{array}{l}\text { Vidal CAG, Pizzaro CAV, } \\
\text { Arriagada AA }\end{array}$ & $\mathrm{F}$ & 52 & 34 & V class cavity, turbine & & $\begin{array}{l}\text { Subcutaneus } \\
\text { emphysema }\end{array}$ & Yes \\
\hline $\begin{array}{l}\text { Shuman NJ, Owens BM, } \\
\text { Shelton JT }\end{array}$ & $\mathrm{F}$ & 32 & 16,18 & $\begin{array}{c}\text { Cavity } \\
\text { preparation }\end{array}$ & $\begin{array}{l}\text { Unintentional injury } \\
\text { of the mucosa during } \\
\text { preparation of the cavity }\end{array}$ & $\begin{array}{l}\text { Subcutaneus } \\
\text { emphysema }\end{array}$ & Yes \\
\hline
\end{tabular}




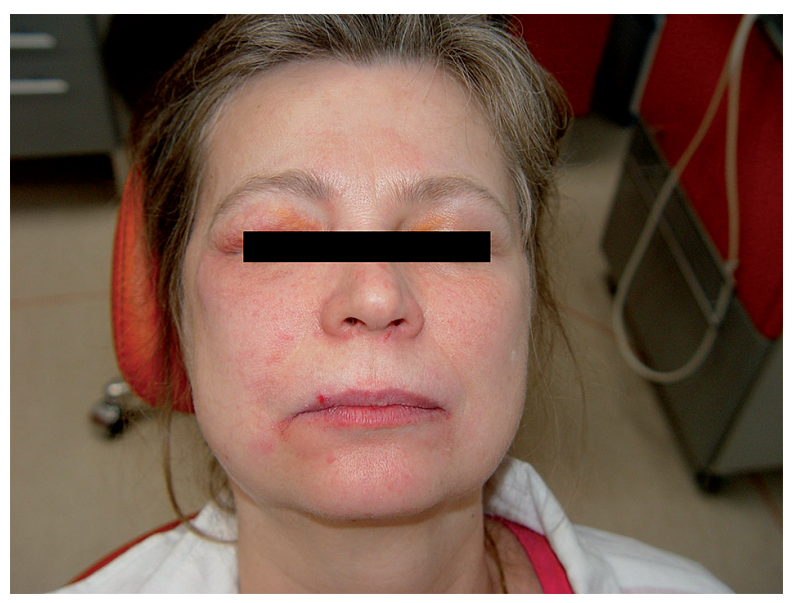

FIGURE 1. Subcutaneus emphysema just after using a dental syringe

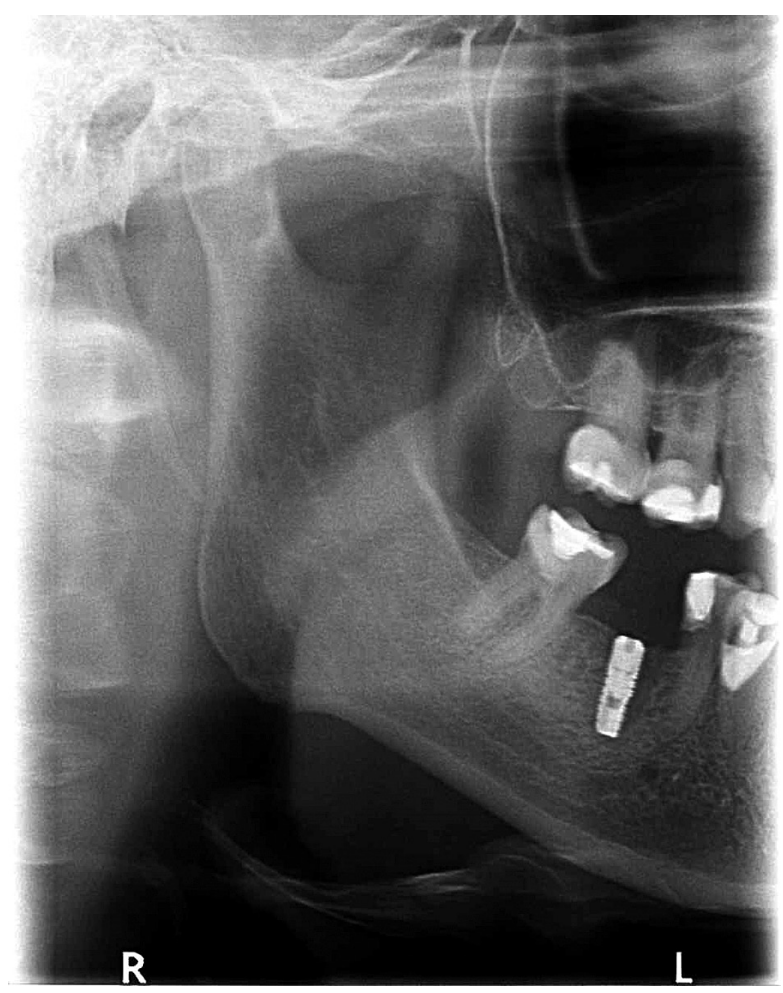

FIGURE 2. Panoramic radiograph showed restoration located under the gingiva in tooth 44

mandibular region, the cheek and the eye (Figure 1). The oedema was not accompanied by pain. In view of the significant oedema, the dentist desisted from further treatment of caries in tooth 44 . A panoramic radiograph was taken, which showed a relatively low descension of the subgingival margin in tooth 44 (Figure 2). The patient was informed of the situation and was asked to register for a follow-up visit. The following day, the soft tissues oedema increased when compared to the immediate occurrence of emphysema (Figure 3). After a week, the oedema completely subsided; how-

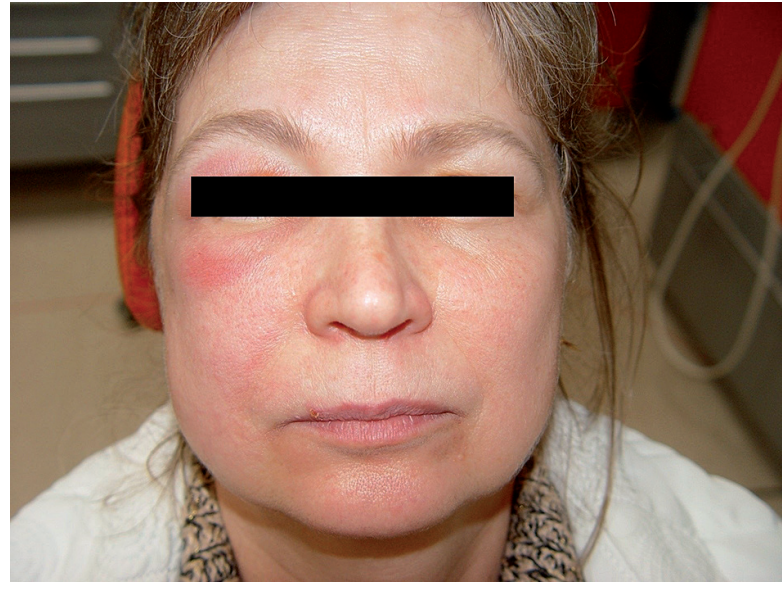

FIGURE 3. Subcutaneus emphysema 24 hours later

ever, the patient did not decide to continue treatment of tooth 44 .

\section{DISCUSSION}

Subcutaneous emphysema is one of the less common complications in dentistry [2]. Regardless of the type of dental procedure performed, the cause of oedema formation is due to air under pressure being forced into a soft tissue region, which usually occurs as a result of damage/breakage of natural barriers (e.g. periodontal space, periodontal pocket, alveolar bone, parotid duct). In the described case, the absence of an attached gingiva was considered as the probable cause of the occurrence of emphysema. Clinically, emphysema manifests itself as increased oedema of the facial soft tissue without changing its colour. Emphysema is not usually accompanied by pain symptoms. However, if it does appear, the pain is changeable and short-lived. Sometimes patients complain of pain during the appearance and enlargement of the oedema [3]. In addition, there may be difficulties in moving the head and when swallowing, especially in cases where the oedema has spread around the neck [16]. Emphysema occurs most often during treatment or shortly after its completion [7]. However, there was a case where the symptoms of emphysema appeared only one day after the surgery [17]. Typically, soft tissue oedema disappears spontaneously after 3 to 10 days from the moment of appearance.

The sudden occurrence of oedema of the face and/or neck following dental surgery requires differential diagnostics, which should take into account the possibility of a haematoma, inflammation of the connective tissue or the so-called cellulitis, an anaphylactic reaction, or angioedema (vascular and motor oedema) [3, 6, 15, 18]. The accumulation of blood within the submucosal or subcutaneous tissue contributes to the formation of a haematoma which, in addition to local volume enlargement of the tissue, manifests itself in its bruising. 
It may be accompanied by pain and/or inflammation [19]. Cellulitis is an acute, diffuse inflammation of the skin or subcutaneous tissue, which is accompanied by both local and systemic symptoms. The inflamed tissue is tender when palpated/touched, swollen, red, hot and painful. There may also be efflorescence in the form of blisters, or petechiae. In advanced states, fever, chills, sweating, and headaches may occur [19]. Angioedema Quincke's/angioneurotic oedema is a hypersensitivity reaction characterised by subcutaneous or submucosal tissue oedema caused by increased vascular endothelial permeability and the passage of tissue fluid into the extravascular space $[19,20]$. It applies most often to lips, eyelids, the mucosa of the mouth and cheek, and, therefore, to tissues containing large volumes of loose connective tissue. Angioedema develops within a few minutes or gradually over the span of several hours and it subsides quite quickly (24-36 h). It is not accompanied by pain but rather by a feeling of tension and burning, and sometimes superficial blisters may appear. It is important to bear in mind the dangers of dyspnoea occurring in the patient when the oedema involves the larynx tissues [21]. Emphysema is often confused with an allergic reaction. Sometimes the dentist considers its occurrence in patients who have been administered an anaesthetic. In these cases, it should be verified whether the case at hand is that of a real allergy or just a vasovagal reaction following an injection, which can be mistaken for an allergic reaction to the local anaesthetic [19]. The least dangerous symptoms of an allergic reaction are skin changes, which may occur in the form of pruritus, redness, oedema, urticaria or erythema [19]. An allergic reaction may occur immediately (type I - anaphylactic shock, urticaria, angioneurotic oedema) or with a delay (type IV - contact allergy) [22]. A pathognomonic symptom of pneumothorax is the characteristic crackling of tissue during palpation, which allows emphysema to be distinguished from the above-mentioned conditions [3]. In patients with neck and/or mediastinum oedema, it is necessary to take an X-ray and perform computer aided tomography or magnetic resonance imaging that will facilitate the correct diagnosis $[16,19]$. The patient ought to be informed by their dentist that if their well-being deteriorates, they should report to the emergency room, especially if breathing problems occur.

Although the majority of emphysemas which occur due to dental reasons pertain to the subcutaneous tissue, there have been reports of air leakage into other tissue spaces, such as the mediastinum or the retropharyngeal space. The presence of air in the mediastinum or the medial space can lead to cardio-respiratory complications [23]. In patients with oedema located in the pericardium, changes in the ECG image are also observed [24]. Symptoms that may indicate the presence of oedema in the mediastinum are dyspnoea, back or chest pain and the so-called Hamman's symptom, i.e. a pulse-like sound of air moving in the mediastinum [17].
In patients with oedema, antibiotics are prophylactically recommended. This treatment aims to prevent the occurrence of a secondary infection, e.g. connective tissue inflammation or fascial necrosis. It is assumed that air entering other tissues from the mouth contains numerous species of bacteria that may cause the development of an infection $[3,6]$. There is no clear information in the literature about the validity of administering antibiotics in protecting patients from secondary infections [23, 25-31]. In the majority of reported cases, physicians employed prophylactic antibiotic therapy in their patients $[23,25,26]$. There were also some doctors who did not choose antibiotics, nor did they report any complications [27-31]. Antibiotics were also not used in the above-described case.

The dentist can reduce the risk of emphysema occurrence, e.g. by conducting endodontic treatment in a rubber dam, by choosing not to use hydrogen peroxide to rinse root canals, or further by not drying the canals with compressed air from an air syringe and paying attention to the direction of the air outlet from the rear parts of the dental handpieces $[7,14]$. During laser work the dentist should avoid concentrating the laser beam for a long time in one place, especially when working in narrow spaces, such as in the case of a submucosal abscess and by accordingly adjusting the flow of the air which cools down the laser [11]. When performing preventative air abrasion treatment, the tip of the nozzle should not be directed towards the epithelial attachment or towards the gingival groove, whereas it is recommended to exercise extreme caution when working in the area of deep periodontal pockets [32]. Following dental procedures, especially those in the field of surgery, the patient should be advised to refrain from smoking cigarettes, coughing, sneezing, vomiting and blowing their nose for a certain period of time; this restriction also involves other activities which increase the pressure in the mouth $[3,33]$. During treatment, the patient's behaviour should be closely monitored and all their complaints ought to be responded to accordingly. This is of crucial importance, as a simple subcutaneous emphysema may cause a pulmonary embolism, which in the absence of a prompt reaction on the part of the physicians can lead to a patient's death [33].

\section{CONCLUSIONS}

This article presents the case of an iatrogenic emphysema which occurred when drying the treatment area by means of a dental air syringe. The emphysema is usually caused by introducing air under pressure into the soft tissues. However, the use of a dental air syringe is not the only cause of the formation of emphysema. Although emphysema tends to be a harmless medical complication, it should be remembered that there is always a risk of serious consequences which require 
specialist treatment. Prompt identification of the symptoms, differential diagnostics, and then making the right diagnosis enables quick and effective treatment.

\section{CONFLICT OF INTEREST}

The authors declare no potential conflicts of interest with respect to the research, authorship, and/or publication of this article.

\section{References}

1. Salib RJ, Valentine P, Akhtar S. Surgical emphysema following dental treatment. J Laryngol Otol 1990; 113: 756-758.

2. Torgay A, Aydin E, Cilasun U, et al. Subcutaneus empysema after dental treatment: a case report. Paediatr Anaesth 2006; 16: 314-317.

3. McKenzie S, Rosenberg M. Iatrogenic subcutaneus emphysema of dental and surgical origin: a literature review. J Oral Maxillofac Surg 2009; 67: 1265-1268.

4. Iqbal M, Ikram M, Raza F. Surgical emphysema in the neck as a result of dental procedure. Ear Nose Throat J 2005; 84: 723-724.

5. Bohnenkamp DM. Subcutanoeus facial emphysema resulting from routine tooth preparation: a clinical report. J Prosthet Dent 1996; 76: 1-3.

6. Frühauf J, Weinke R, Pilger U, et al. Soft tissue cervicofacial emphysema after dental treatment: report of 2 cases with emphasis on the differentia diagnosis of angioedema. Arch Dermatol 2005; 141: 1437-1440

7. Uyanik LO, Aydin M, Buhara O, et al. Periorbital emphysema during dental treatment: a case report. Oral Surg Oral Med Oral Pathol Oral Radiol Endod 2011; 112: 94-96.

8. Liebenberg WH, Crawford BJ. Subcutaneus, orbital and mediastinal emphysema secondary to the use of an air-abrasive device. Quintessebce Int 1997; 28: 31-38.

9. Hata T, Hosoda M. Cervicofacial subcutaneus empysema after oral laser surgery. Br J Oral Maxillofac Surg 2001; 39: 161-162.

10. Matsuzawa N, Kinoshita H, Shirozu T, et al. Mediastinal emphysema caused by a dental laser. Asian J Oral Maxillofacial Surg 2010 22: 216-219.

11. Mitsunga S, Iwai T, Aoki N, et al. Cervicofacial subcutaneus and mediastinal emphysema caused by air cooling spray of dental laser Oral Surg Oral Med Oral Pathol Oral Radiol 2013; 115: e13-e16.

12. Willy PJ, McArdle P, Peters WJ, et al. Surgical emphysema and Colllet-Sicard syndrome after cryoblockade of the inferior alveolar nerve. Br J Oral Maxillofac Surg 2003; 41: 190-192.

13. Shuman NJ, Owens BM, Shelton JT. Subcutaneous emphysema after restorative dental treatment. Compend Contin Educ Dent 2001; 22: 38-40

14. Kim Y, Kim MR, Kim SJ. Iatrogenic pneumomediastinum with extensive subcutaneus emphysema after endodontic treatment: report of 2 cases. Oral Surg Oral Med Oral Pathol Oral Radiol Endod 2010; 109: 114-119.

15. An GK, Zats B, Kunin M. Orbital, mediastinal and cervicofacial subcutaneous emphysema after endodontic retreatment of a mandibular premolar: a case report. J Endod 2014; 40: 880-883.

16. Liatiri S. Subcutaneous emphysema after root canal therapy. Balk J Stom 2016; 16: 10-15.

17. Arai I, Aoki T, Yamazaki H, Kaneko A. Pneumomediastinum and subcutaneus amphysema after dental extraction detected incidentally by regular medical checkup: a case report. Oral Surg Oral Med Oral Pathol Oral Radiol Endod 2009; 107: e33-e38.

18. Steelman RJ, Johannes PW. Subcutaneous emphysema during restorative dentistry. Int J Paediatr Dent 2007; 17: 228-229.

19. 19. Vargo RJ, Potluri A, Yeung AY, et al. Cervicofacial subcutaneous emphysema: a clinical case and review of the literature. Gen Dent 2016; 64: 68-71.
20. Mather AJ, Stoykewych AA, Curran JB. Cervicofacial and mediastinal emphysema complicating a dental procedure. J Can Dent Assoc 2006; 72: 565-568.

21. Obtułowicz K. Obrzęk naczynioruchowy - trudny problem kliniczny. Alergia Astma Immunologia 2006; 11: 166-171.

22. Langlais RP, Miller CS, Szponar E (eds.). Choroby błony śluzowej jamy ustnej. Wydawnictwo Medyczne Urban \& Partner, Wrocław 1997; 88.

23. Smatt $\mathrm{Y}$, Browaeys $\mathrm{H}$, Genay A, et al. Iatrogenic pneumomediastinum and facial emphysema after endodontic treatment. Br J Oral Maxillofac Surg 2004; 42: 160-162.

24. Reiche-Fischel O, Helfrick JF. Intraoperative life-threatening emphysema associated with endotracheal intubation and air insufflation devices: report of two cases. J Oral Maxillofac Surg 1995; 53: 1103-1107.

25. Chung IH, Moon HJ, Suh JD, et al. Cervicofacial emphysema and mediastinitis following restorative dental treatment - a case report. Br J Oral Maxillofac Surg 2006; 44: 376.

26. Uehara M, Okumura T, Asahina O, et al. Subcutaneus cervical emphysema induced by a dental air syringe: a case report. Int Dent J 2007; 57: 286-288.

27. Chan DC, Myers T, Sharaway M, et al. A case for rubber dam application- subcutaneus emphysema after class V procedure. Oper Dent 2007; 32: 193-196.

28. Sujeet K, Shankar S. Prevertebral emphysema after a dental procedure. N Eng J Med 2007; 356: 171.

29. Capes JO, Salon JM, Wells DL, et al. Bilateral cervicofacial, axillary and anterior mediastinal emphysema: a rare complication of third molar extraction. J Oral Maxillofac Surg 1999; 57: 996-999.

30. Vidal CA, Pizarro CA, Arriagada AA. Subcutaneous emphysema secondary to dental treatment: case report. Med Oral Patol Oral Cir Bucal 2007; 12: 76-78.

31. Marek E, Lipski M. Odma powietrzna w trakcie leczenia endodontycznego. Mag Stomatol 2013; 23: 110-112.

32. Toniollo M, Terada AS, Yamaji MA. Subcutaneous emphysema after treatment through air- abrasive device: case report. Braz Dent Sci 2016; 19: 106-110.

33. Aquillina P, McKellar G. Extensive surgical emphysema following restorative dental treatment. Emerg Med Australas 2004; 16 : 244-246. 